\title{
Prototropic and metallotropic migration of isolobal fragments on indol rings. Theoretical study and NBO analysis

\author{
S. jameh-Bozorghi ${ }^{1 *}$, Z. Javanshir ${ }^{1} \&$ D. Nori-Shargh ${ }^{1}$
} \\ 1Chemistry Department, Faculty of science, Arak Branch, Islamic Azad University, Arak, Iran e-mail: Sjamehbozorgi@gmail.com
}

\begin{abstract}
Molecular structures, energies, NBO analysis and sigmatropic behaviour of 1-Indenyl(dihydro)borane (1) and 1Indenyl-threecarbonylcobalt(I) (2) were investigated using DFT and ab initio molecular orbital methods. In these compounds $\mathrm{BH}_{2}$ and $\mathrm{Co}(\mathrm{CO})_{3}$ fragments are isolobal. The Results of calculations using $B_{3} L Y P$, HF and MP2 methods [Basis set $6-311+\mathrm{G}^{* *}$ ] showed that $-\mathrm{BH}_{2}$ and $-\mathrm{Co}(\mathrm{CO})_{3}$ had similar behaviour in sigmatropic shifts. Prototropic shifts in compounds 1 and 2 have similar mechanisms too. Results showed that metallotrotropic shift is faster than Prototrpic shift in compounds $\mathbf{1}$ and 2 . The activation energies $(\mathrm{Ea})$ of Prototropic shift in compounds 1 and 2 are 18.83 and $17.38 \mathrm{kcal} . \mathrm{mol}^{-1}$. These energies are higher than $-\mathrm{BH}_{2}$ shifts in compound 1 (10.11 kcal.mol $\left.{ }^{-1}\right)$

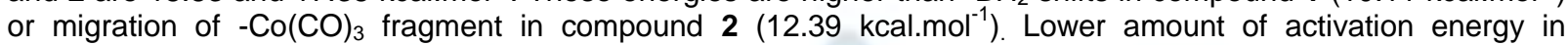
borotropic shift and cobalt's fragment shift show that rotation of boron and cobalt on the indol ring can happen in the ambient temperature. Calculation results revealed that migration of proton and $\mathrm{Co}(\mathrm{CO})_{3}$ was carried out via suprafacial[1,2]-sigmatropic mechanism while $-\mathrm{BH}_{2}$ shift took place via antrafacial $[1,3]$-rearangment.
\end{abstract}

\section{Keywords}

Ab initio; Isolobal; indol; sigmatropy; metallotropic; prototropic.

\section{Council for Innovative Research}

Peer Review Research Publishing System

\section{Journal: Journal of Advances in Chemistry}

\author{
Vol. 5, No. 1 \\ editor@cirworld.com




\section{INTRODUCTION}

Fluxional $\sigma$-cyclopentadienyl compounds such as $\left(\eta^{1}-\mathrm{C}_{5} \mathrm{H}_{5}\right)_{2} \mathrm{Hg}$ and $\left(\eta^{5}-\mathrm{C}_{5} \mathrm{H}_{5}\right)\left(\eta^{1}-\mathrm{C}_{5} \mathrm{H}_{5}\right) \mathrm{Fe}(\mathrm{CO})_{2}$ were first discovered by Piper and Wilkinson in 1965[1]. The 1,2-migration of carbon-group elements in cyclopentadienyl compounds was first experimentally discussed by Fritz and Kreiter for silicon-, germanium-, tin-substituted cyclopentadienes [2,3]. Ab initio study of behaviours, metallotropic 1,2-shift and prototropic 1,2-shift of cyclopentadienyl(trimethyl)-Silane, -German and Stannane were carried out by Nori-shargh et-al in 2003. In this research calculation results showed that allylic isomer is the most stable isomer of the mentioned compounds. Also, it was revealed that prototropic shift is much slower than metallotropic shift [4]. Gridnev and Meller investigated fluxional behaviour of 1- Indenyl(dihydro)borane in 1998 [5]. The authors discussed in a non-detailed but essentially correct manner why fast intra-molecular 1,2-migrations of the metal moiety around the 1-Indenyl ring occur. The order of relative thermodynamic stability of triorganoboranes nicely corresponds to the known order for the corresponding hydrocarbons [6].

Fluxional 1-indenyl(diethyl)borane (3a) was prepared from indenyllithium and diethylboron chloride in hexane [7]. (Scheme 1)

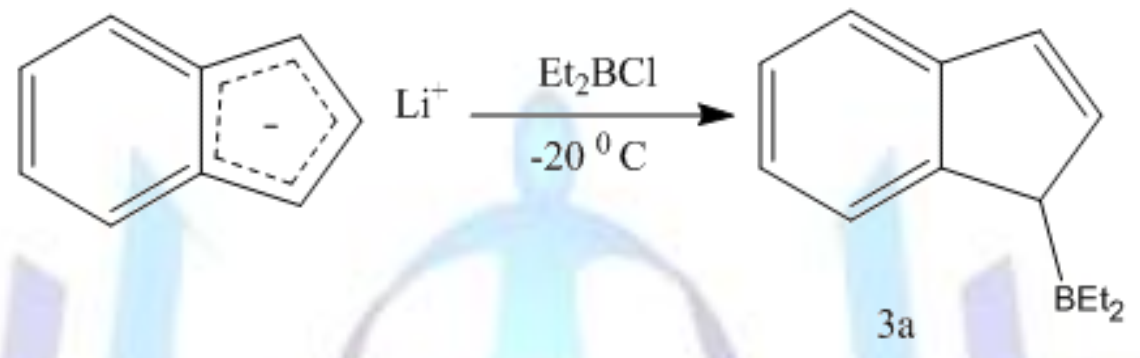

Scheme 1: Preparation of 1-indenyl(diethyl)borane

NMR spectra of borane $3 \mathbf{a}$ was taken in the temperature interval $25-80{ }^{\circ} \mathrm{C}$ and three cross-peaks corresponding to the migrations of the diethylboryl group from position 1 to position 3 were found [7].

A sigmatropic migration of hydrogen takes place at elevated temperatures in $\mathbf{3 a}$. This leads to the establishment of a dynamic equilibrium between the three isomers $\mathbf{3 a}$, 3b, and $\mathbf{3 c}$ (Scheme 2). A small amount (about $6 \%$ ) of 2 -indenyl (diethyl) borane $\mathbf{3 c}$ apparently appears by a [1,2]-H shift in the iso-indenyl intermediate $\mathbf{3 e}$, which is formed from $\mathbf{3 a}$ via two consequent [1,3]-B shifts [7].

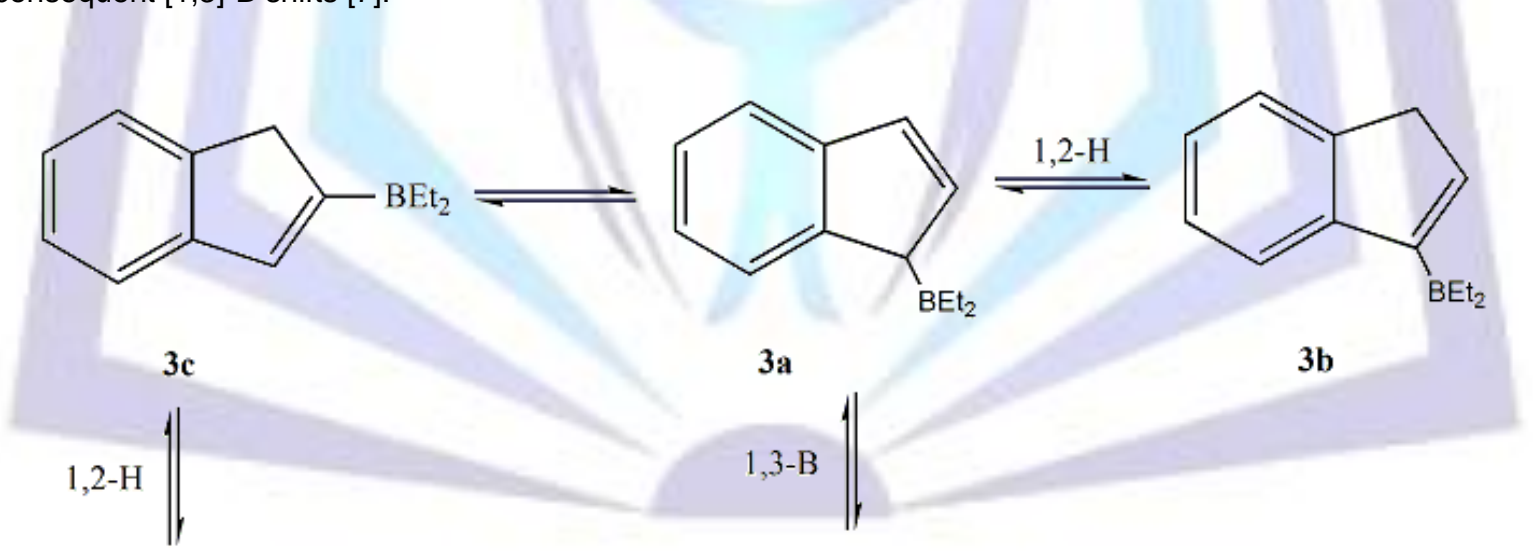<smiles>BrC1C=c2ccccc2=C1</smiles>

$3 e$<smiles>CCC12C=CC=CC1=CC=C2</smiles>

$3 d$

Scheme 2: sigmatropic migration of hydrogen and boron

Sigmatropic migration of many fragments on aromatic rings has been observed. These compounds are fluxional. Experimental [1] and theoretical [4] studies on barrier energies and rate of $(\sigma)$ metallotropic and $(\sigma)$ prototropic shift on Fluxional compounds were carried out. 
1H-NMR, 13C-NMR, mass spectrometer and IR studies of the structures of 1-Indenyl(dihydro)borane indicated that the isomer 3 is the most stable isomer. In solution state, four compounds have been found to undergo rapid metallotropic shifts much faster than prototropic shifts which give allylic nonfluxional isomers [8-15].

The isolobal principle has been devised by Roald Hoffmannin in Organometallic Chemistry [16]. The methyl radical is isolobal with the metal carbonyl species manganese pentacarbonyl $\mathrm{Mn}(\mathrm{CO})_{5}$ because both molecules have a single electron in a hybrid orbital pointing away from the plane of the molecule (though they are not isoelectronic). This resemblance is reflected in the chemistry of both molecules. As the methyl radical can dimerize to ethane, $\mathrm{Mn}(\mathrm{CO})_{5} \mathrm{can}$ dimerize to $(\mathrm{CO})_{5} \mathrm{Mn}-\mathrm{Mn}(\mathrm{CO})_{5}$ and both radicals can form $\mathrm{Mn}(\mathrm{CO})_{5} \mathrm{CH}_{3}$. So, it can be inferred that $-\mathrm{BH}_{2}$ and $-\mathrm{Co}(\mathrm{CO})_{3}$ are isolobal groups. Those were showed their HOMO and LUMO diagram in fig 1.

As the above mentioned, fluxional behaviour of boron in indenyl(dihydro)boran observed [5], but mechanism of this behaviour was not investigated. On the other hand, any experimental or theoretical investigation about structural, fluxional behaviour and sigmatropic shifts mechanism of isolobal compound with indenyl(dihydro)boran not performed.

The main goal of this work is investigation of sigmatropic behaviour of indenyl(dihydro)boran. Also, presentation, investigation of structural and fluxional properties and sigmatropic shifts mechanism for inorganic isolobal compound with indenyl(dihydro)boran and comparison together.

Calculation were performed by ab initio molecular orbital (MO) and hybrid density functional theory (hybrid-DFT: $B 3 L Y P / 6-311+G^{* *}$ based method using the GAUSSIAN 2003 package of programs and NBO 3.1 [17-21].

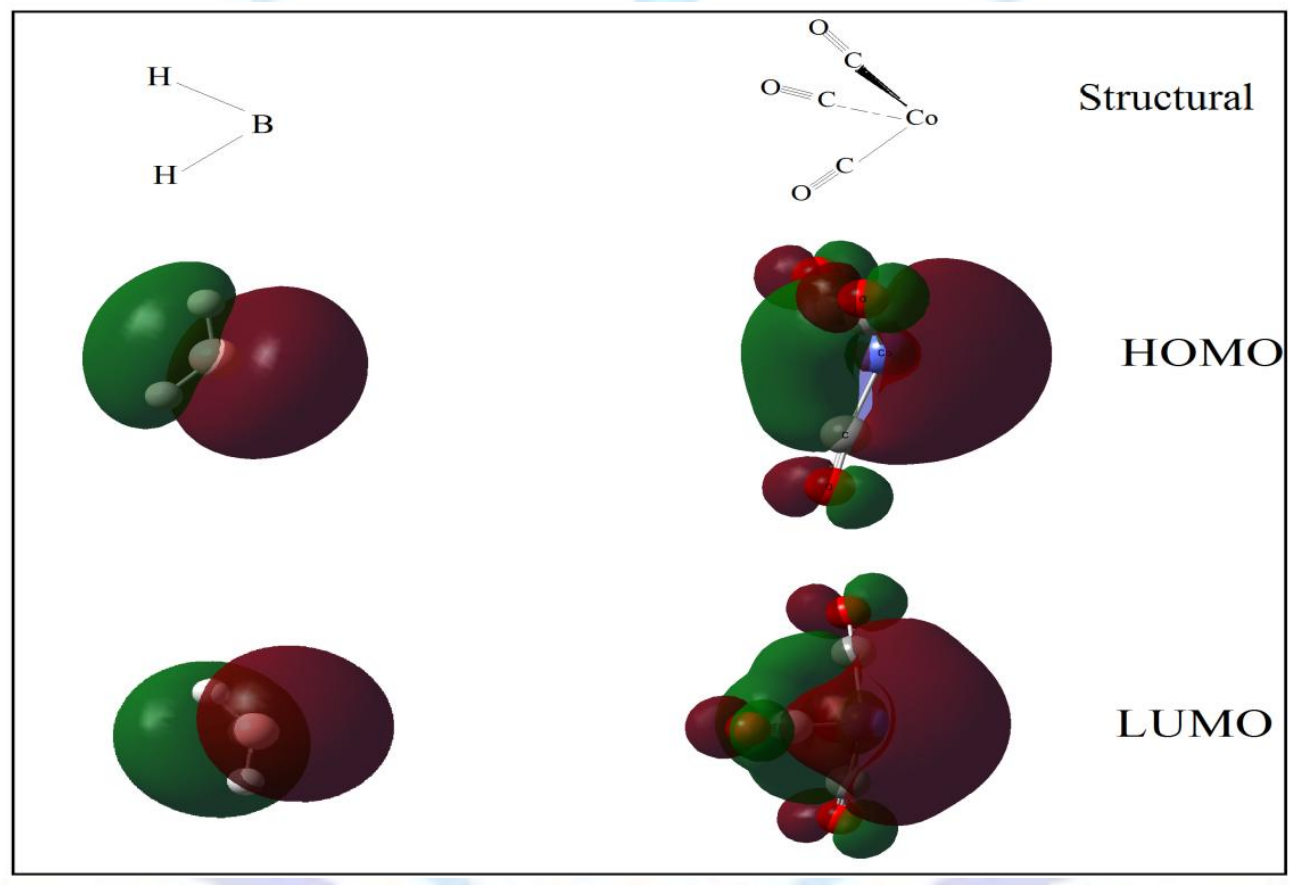

Figure 1:Similarity of HOMO and LUMO diagrams for optimized structure of $\mathrm{BH}_{2}$ and $\left[\mathrm{Co}(\mathrm{CO})_{3}\right]$

The nature of the stationary points for compounds has been determined by virtue of the number of imaginary frequencies. For minimum state structures, only real frequency values, and in the transition state only single imaginary frequency values (with a negative sign) are accepted.

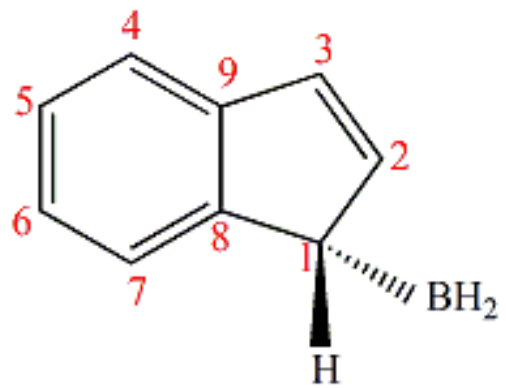

1

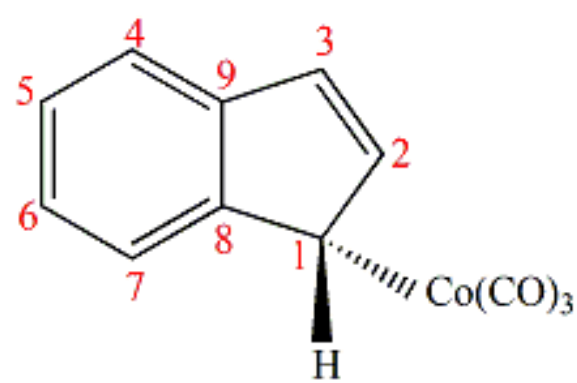

2

Scheme 3: Structure of compounds 1 and 2 


\section{CALCULATION DETAILS}

$A b$ initio molecular orbital $(\mathrm{MO})$ calculations were carried out using $B 3 L Y P / 6-311+\mathrm{G}^{* *}$ level of theory with the GAUSSIAN 2003 package of programs [21] on a personal computer.

Vibrational frequency amounts for all ground and transition state structures were calculated at $B 3 L Y P / 6-311+G^{* *}$ level of theory for compound $\mathbf{1}$, but for compound $\mathbf{2}$, due to their large size, they were calculated at $B 3 L Y P / l a n l 2 \mathrm{dz}$ level of theory.

The Basis series and method dependencies were probed by single point energies computed at $B 3 L Y P / 6-311+G^{* *}$, $\mathrm{HF} / 6-311+\mathrm{G}^{* *}, \mathrm{MP} 2 / 6-311+\mathrm{G}^{* *}$ optimized geometries.

Energy-minimum molecular geometries were located by minimizing energy with respect to all geometrical coordinates without imposing any structurally symmetrical constraints and transition state structures were obtained by QST2 subroutine. [22, 23] Natural Bond Orbital (NBO) analysis was then performed at the $B 3 L Y P / 6-311+G^{* *}$ level by the NBO 3.1 program included in the GAUSSIAN 03 package of programs.

\section{RESULT AND DISCUSSION}

Structural properties, energies behaviour and NBO analysis were investigated using ab initio molecular orbital (MO) and hybrid density functional theory (hybrid-DFT: $B 3 L Y P / 6-311+\mathrm{G}^{* *}$ ) for compounds 1 and 2 . In these two compounds $[1,2]$ hydrogen shifts occur by a symmetry-allowed suprafacial rearrangement, as illustrated in scheme 4 . Contrary to [1,2] sigmatropic hydrogen shift, however, thermal $[2,3]$ hydrogen shifts are unknown.

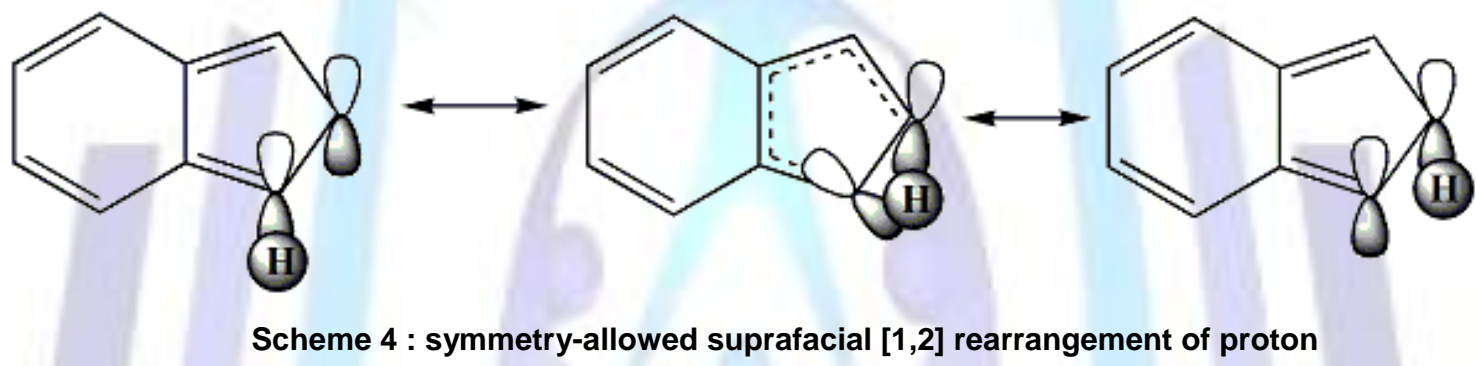

$\mathrm{BH}_{2}$ shifts cannot occur through [1,2] superafacial rearrangement. This migration is a $[1,3]$ antrafacial rearrangement (scheme 5), But $\mathrm{Co}(\mathrm{CO})_{3}$ shifts can occur through [1,2] superafacial rearrangement as illustrate in (scheme 6). In compounds 1 and 2 prototropic 1,2-shifts hydrogen migration occurred stepwise from $C(1)$ to $C(2)$ and from $C(2)$ to $C(3)$. Also, in compound 2 the $\mathrm{Co}(\mathrm{CO})_{3}$ fragment migration occurred stepwise from $\mathrm{C}(1)$ to $\mathrm{C}(2)$ and from $\mathrm{C}(2)$ to $C(3)$ similar hydrogen shift (see Figures 3 and 4). But in compound $1-\mathrm{BH}_{2}$ fragment migration did not occur from $\mathrm{C}(1)$ to $\mathrm{C}(2)$; it only occurred from $\mathrm{C}(1)$ to $\mathrm{C}(3)$ through $[1,3]$.

HOMO diagram of transition state structure of compounds $\mathbf{1}$ and $\mathbf{2}$ are shown in fig 2. In HOMO diagram of compound 1 one node is exist on $\mathrm{C}(2)$ atom, then sigmatropic shift from $\mathrm{C}(1)$ to $\mathrm{C}(2)$ is impossible, but suitable overlap of frontier orbitals of $\mathrm{BH}_{2}$ with $\mathrm{C}(1)$ and $\mathrm{C}(3)$ produce a [1,3]-sigmatropic shift of $\mathrm{BH}_{2}$ (see fig 2). On the other hand $\mathrm{HOMO}$ diagram of compound 2 showed that suitable overlap of orbitals for [1,2]-sigmatropic shift of $\mathrm{Co}(\mathrm{CO})_{3}$ fragment is appear and not node on $\mathrm{C}(2)$ of $\mathrm{C}_{5} \mathrm{H}_{5}$ ring. Therefore 1,2-metallotropic shift would be occurred.

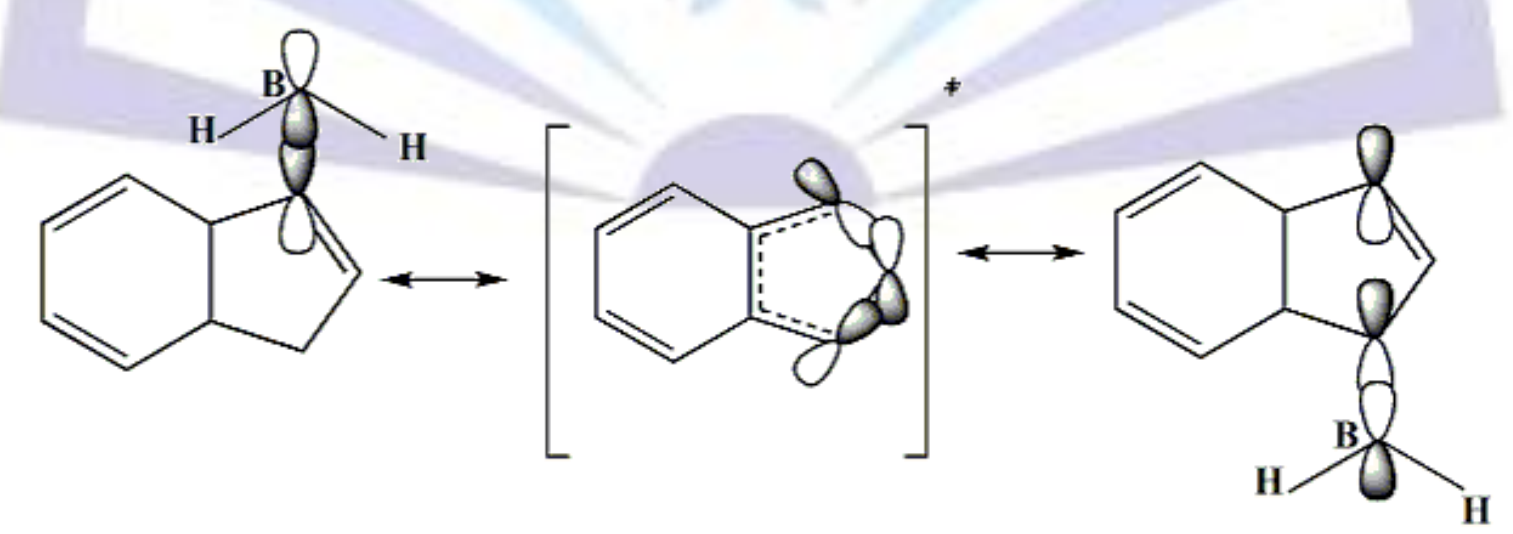

Scheme $5:[1,3]$ antrafacial rearrangement of $\mathrm{BH}_{2}$ fragment 


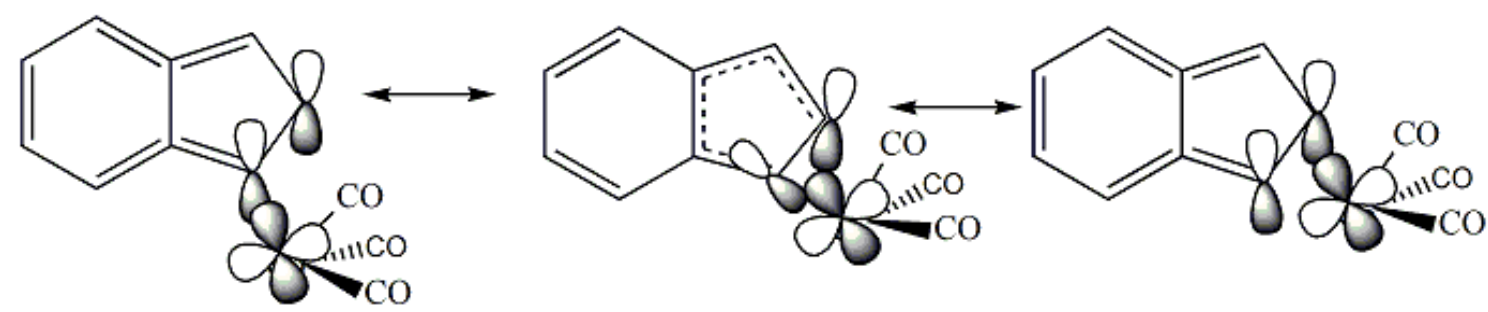

Scheme $6:[1,3]$ symmetry-allowed suprafacial $[1,2]$ rearrangement of $\mathrm{Co}(\mathrm{CO})_{3}$

When $\mathrm{BH}_{2}$ is in vinylic position these compounds are not in ground state. Infra Red (IR) vibration frequencies (an imaginary frequency) and Aromatic Stabilization Energy (ASE $=3.62 \mathrm{Kcal} . \mathrm{mol}-1$ ) as well as bond lengths of C-B that increased to 1.69 Angstrom results showed that this structure is a transition state one (fig. 3 and table 1). Also IRC calculation confirmed that $\mathrm{BH}_{2}$ in vinylic position is a transition structure (fig.5).

Prototropic and metallotropic shift pathways of compounds 1 and 2 are shown in Figures 3 and 4, respectively.

Structural parameters, total electronic $\left(E_{e l}\right)$ energy, corrected zero point $\left(Z P E^{c}\right)$ energies of compounds $\mathbf{1}$ and $\mathbf{2}$, calculated on the $a b$ initio and DFT levels of theory are given in Tables $1-7$. The migration mechanisms for the $\mathrm{BH}_{2}$, $\mathrm{Co}(\mathrm{CO})_{3}$ and hydrogen were also investigated and structure of ground states and transition states of all compounds were investigated. Calculated results revealed that Indol rings are planar in the ground state and non planar in transition state for compounds 1 and 2 . $\delta_{1239}$ and $\delta_{2398}$ values are 0.0000 for ground state of compounds 1 and 2 while these values are 16.34 and -10.04 for compound 1 and -3.05 and 2.56 for compound 2, respectively( see table 1 and 4 )

Also, reaction pathways were shown in Figures 3 and 4. In metallotropic 1,2-shifts, the reaction pathways are symmetrical and in the transition state structure, the $\mathrm{BH}_{2}, \mathrm{Co}(\mathrm{CO})_{3}$ groups are equidistant from two carbon atoms of the $\mathrm{C}_{9} \mathrm{H}_{7}$ rings (see Tables 1 and 4 ). According to the results, comparing $\mathrm{C}-\mathrm{B}$ and $\mathrm{C}-\mathrm{Co}$ shows an increase in bond lengths while in the contrary, the dissociation of a C-B bond is easier than that of a C-Co bond which in turn, leads to the migration of the metal around the indol ring with a lower energy barrier. This result is in good agreement with the mentioned experimental data.

As it can be inferred from the Figures 3 and 4 the prototropic 1,2-shifts require higher energy barrier than metallotropic 1,2-shifts, consequently, the rate of this process is much slower than that of metal migration.

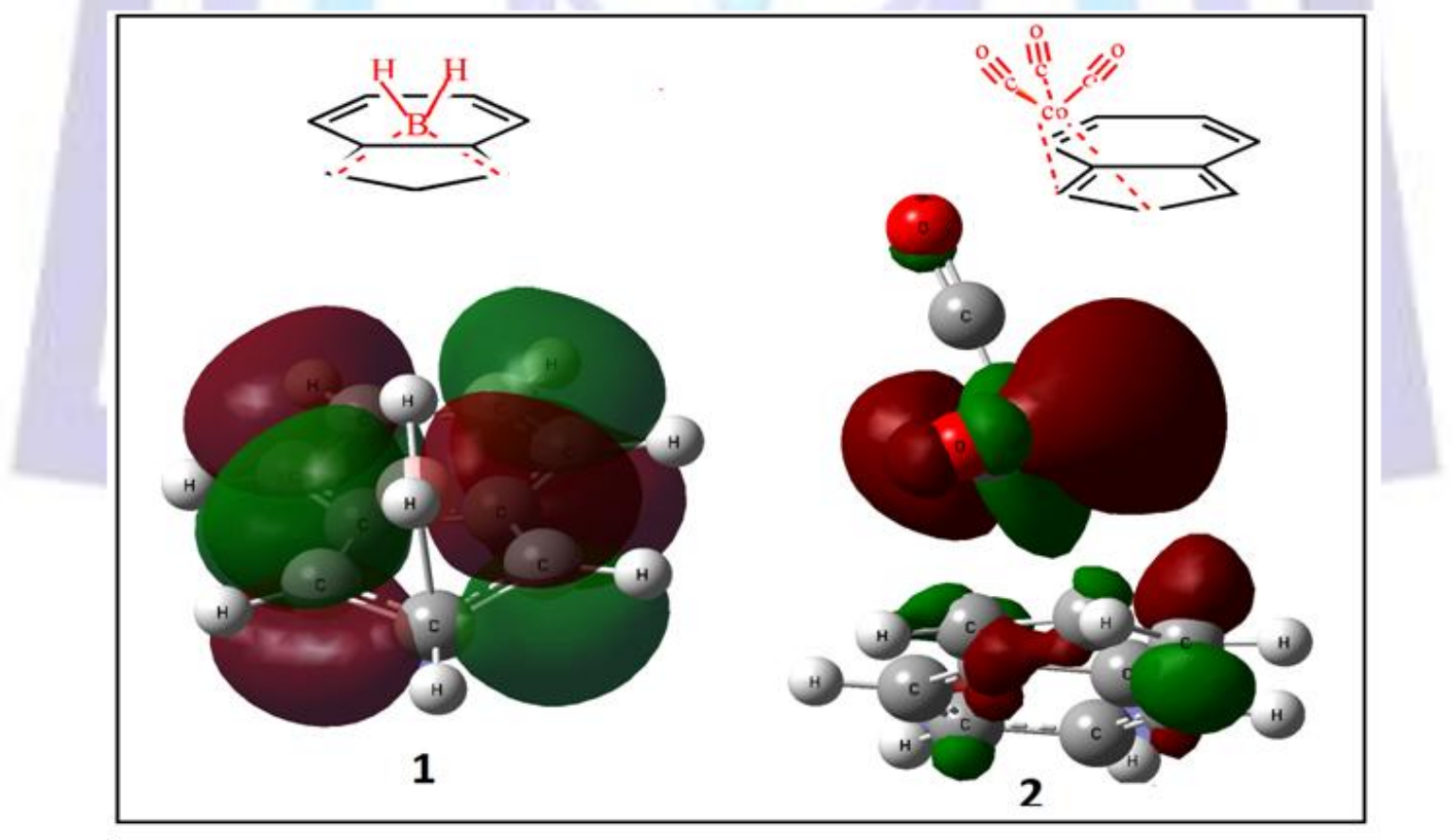

Figure 2: HOMO diagram of optimized metallotropic transition state structural of compound 1, 2

$A b$ initio and DFT calculation results showed that the energy barrier of prototropic shift in compound 1 and 2 from $\mathrm{C}(1)$ to $\mathrm{C}(2)$ is equal to the prototropic shift from $\mathrm{C}(2)$ to $\mathrm{C}(3)$ ( see table 1 ). Calculation results revealed that $\mathrm{BH}_{2}[1,2]$ migration need $10.11 \mathrm{kcal}^{\mathrm{mol}}{ }^{-1}$ that is a lower migration energy comparing to $\mathrm{Co}(\mathrm{CO})_{3}(12.39 \mathrm{kcal}$.mol-1) while bond lengths of C-B and C-Co are 1.562 and 2.082 Angstrom. On the other hand NBO calculation results showed that electron occupancies of $\mathrm{C} 1-\mathrm{B}$ bond is 1.9 while occupancies of. $\mathrm{C} 1-\mathrm{Co}$ bond is 1.74 . The mentioned results concluded that $\mathrm{C}$ $\mathrm{Co}$ bond has an irregular strength. The reason for straight of $\mathrm{C}$-Co bond and the higher level of the barrier energy for $\mathrm{Co}(\mathrm{CO})_{3}$ migration is related to the existence of a $\pi$ back bonding between Co and $\mathrm{C}$. B3LYP/6-311+G** results showed 
that the prototropic shift barrier energy for compound 1 is $30.4 \mathrm{Kcal} \mathrm{mol}-1$ and for compound 2 is $50.3 \mathrm{Kcal}$ mol-1. Therefore, it was revealed that prototropic shifts for compound 1 have lower migration energy comparing to compound 2 . It can be concluded that the prototropic 1,2-shifts occur only at higher temperatures. These results have a good agreement with structural and NBO results.

\section{CONCLUSIONS}

The calculation results at $B 3 L Y P / 6-311+\mathrm{G}^{* *}, \mathrm{HF} / 6-311+\mathrm{G}^{* *}$ and $\mathrm{MP} 2 / 6-311+\mathrm{G}^{\star *}$ levels of theory show that the most stable isomers of compounds 1 and 2 are the allylic isomers.

$\mathrm{BH}_{2}$ shift in compound 1 cannot occurred via [1,2] migration and performed via $[1,3]$ sigmatropic shift because compound 1 has one node on $\mathrm{C}(2)$ atom in $\mathrm{HOMO}$ diagram while in compound 2 this migration occurred at [1,2]metallotropic shift because HOMO diagram of this compound showed suitable overlap of orbitals for [1,2]-sigmatropic shift of $\mathrm{Co}(\mathrm{CO})_{3}$ fragment. In a similar vein, the occurrence of [1,2]-prototrophic shift for the two compounds was easy.

Bond legth of Co-C is longer than B-C and electronic occupancies of Co-C is lower than B-C while sigmatropic barrier energy for $\mathrm{Co}(\mathrm{CO})_{3}$ migration is higher than $\mathrm{BH}_{2}$ migration, because $\mathrm{Co}-\mathrm{C}$ bond has a $\pi$-back bonding which makes it stronger than $\mathrm{B}-\mathrm{C}$.

Barrier height of metalotropic shift is lower than prototrophic shift. Lower amount of activation energy in borotropic shift and cobalt's fragment shift show that rotation of boron and cobalt on the indol ring can happen in the ambient temperature, but prototropic migration occurred at higher temperature.

Table 1. DFT/6-311+G**Calculated Structural Parameters and Energies of the Ground States and TransitionStates of 1-indenyl(dihydro)borane (1).. Bond Lengths are in Angstrom Units $(\AA)$ and Angles in Degrees ()

\begin{tabular}{|c|c|c|c|c|c|c|}
\hline Compounds & 1 & 2 & 3 & $1 \rightarrow 2$ & $2 \rightarrow 3$ & $1 \rightarrow 1$ \\
\hline \multicolumn{7}{|l|}{ Bond lengths } \\
\hline B- $C_{1}$ & 1.56273 & 1.51033 & 1.53260 & 1.51066 & 1.50681 & --- \\
\hline $\mathrm{B}-\mathrm{C}_{2}$ & --- & --- & -- & -- & --- & 1.69025 \\
\hline$C_{1}-C_{2}$ & 1.51135 & 1.51257 & 1.36365 & 1.52426 & 1.43488 & 1.42411 \\
\hline $\mathrm{C}_{2}-\mathrm{C}_{3}$ & 1.34642 & 1.48755 & 1.50246 & 1.39680 & 1.46514 & 1.42408 \\
\hline $\mathrm{C}_{3}-\mathrm{C}_{9}$ & 1.46326 & 1.36747 & 1.51020 & 1.41786 & 1.42143 & 1.45149 \\
\hline $\mathrm{C}_{1}-\mathrm{C}_{8}$ & 1.51212 & 1.39362 & 1.48322 & 1.44162 & 1.43745 & 1.45151 \\
\hline $\mathrm{C}_{3}-\mathrm{H}_{2}$ & 1.08277 & 1.08283 & 1.09811 & 1.08114 & 1.08147 & 1.08004 \\
\hline $\mathrm{C}_{1}-\mathrm{H}_{1}$ & 1.11591 & 1 & --- & 1.36322 & --- & 1.08003 \\
\hline $\mathrm{C}_{2}-\mathrm{H}_{1}$ & & 1.10046 & --- & 1.25449 & 1.26195 & -- \\
\hline $\mathrm{C}_{3}-\mathrm{H}_{1}$ & --- & -- & 1.09811 & & 1.39146 & -- \\
\hline \multicolumn{7}{|l|}{ Occupancy } \\
\hline B- $C_{1}$ & $\delta=1.94532$ & $\delta=1.97749$ & $\delta=1.97686$ & $\delta=1.97792$ & $\delta=1.97432$ & --- \\
\hline $\mathrm{B}-\mathrm{C}_{2}$ & --- & -- & --- & 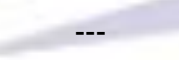 & --- & --- \\
\hline \multirow[t]{2}{*}{$\mathrm{C}_{1}-\mathrm{C}_{2}$} & $\delta=1.97204$ & $\delta=1.97433$ & $\delta=1.98051$ & $\delta=1.90469$ & $\delta=1.97620$ & $\delta=1.95676$ \\
\hline & & & $\pi=1.79633$ & & & \\
\hline \multirow[t]{2}{*}{$\mathrm{C}_{2}-\mathrm{C}_{3}$} & $\delta=1.98112$ & $\delta=1.98029$ & $\delta=1.98053$ & $\delta=1.98158$ & $\delta=1.94330$ & $\delta=1.96830$ \\
\hline & $\pi=1.90399$ & & & & & $\pi=1.52963$ \\
\hline \multirow[t]{2}{*}{$\mathrm{C}_{3}-\mathrm{C}_{9}$} & $\delta=1.97299$ & $\delta=1.97933$ & $\delta=1.97656$ & $\delta=1.97492$ & $\delta=1.97743$ & $\delta=1.97352$ \\
\hline & & $\pi=1.74179$ & & $\pi=1.58434$ & $\pi=1.56231$ & \\
\hline \multirow[t]{2}{*}{$\mathrm{C}_{1}-\mathrm{C}_{8}$} & $\delta=1.97093$ & $\delta=1.97523$ & $\delta=1.96873$ & $\delta=1.97261$ & $\delta=1.97013$ & $\delta=1.97372$ \\
\hline & & $\pi=1.69034$ & & $\pi=1.54679$ & $\pi=1.58574$ & \\
\hline $\mathrm{C}_{3}-\mathrm{H}_{2}$ & $\delta=1.98282$ & $\delta=1.98490$ & $\delta=1.95046$ & $\delta=1.98244$ & $\delta=1.98579$ & $\delta=1.98182$ \\
\hline $\mathrm{C}_{1}-\mathrm{H}_{1}$ & $\delta=1.88938$ & --- & -- & -- & --- & $\delta=1.98362$ \\
\hline $\mathrm{C}_{2}-\mathrm{H}_{1}$ & --- & $\delta=1.93470$ & --- & $\delta=1.54270$ & $\delta=1.53881$ & --- \\
\hline
\end{tabular}




\begin{tabular}{|c|c|c|c|c|c|c|}
\hline $\mathrm{C}_{3}-\mathrm{H}_{1}$ & --- & --- & $\delta=1.95046$ & --- & --- & --- \\
\hline \multicolumn{7}{|l|}{ Bond angles $\left(^{\circ}\right)$} \\
\hline$B-C_{1}-C_{2}$ & 118.02271 & 125.90587 & 123.34432 & 124.92483 & 124.70329 & 56.90268 \\
\hline$B-C_{1}-C_{8}$ & 119.93351 & 128.04433 & 129.36956 & 131.34540 & 129.72983 & --- \\
\hline B- $\mathrm{C}_{2}-\mathrm{C}_{3}$ & --- & --- & --- & --- & --- & 78.20513 \\
\hline $\mathrm{C}_{1}-\mathrm{C}_{2}-\mathrm{C}_{3}$ & 110.62816 & 105.72514 & 112.22000 & 108.75079 & 109.36508 & 107.58036 \\
\hline $\mathrm{C}_{2}-\mathrm{C}_{3}-\mathrm{C}_{9}$ & 109.72225 & 109.17748 & 102.59078 & 108.94560 & 106.98556 & 107.32653 \\
\hline $\mathrm{C}_{3}-\mathrm{C}_{9}-\mathrm{C}_{8}$ & 108.33501 & 108.52808 & 108.73209 & 108.80419 & 107.75667 & 107.50909 \\
\hline $\mathrm{C}_{9}-\mathrm{C}_{8}-\mathrm{C}_{1}$ & 108.51049 & 110.51950 & 109.17101 & 109.74990 & 110.30320 & 107.50903 \\
\hline $\mathrm{C}_{8}-\mathrm{C}_{1}-\mathrm{C}_{2}$ & 102.77879 & 106.04980 & 107.28612 & 103.70446 & 105.56395 & 107.32504 \\
\hline \multicolumn{7}{|l|}{ Torsion angles $\left({ }^{\circ}\right)$} \\
\hline$B-C_{1}-C_{2}-C_{3}$ & 132.84495 & -179.99577 & -179.99263 & 176.18452 & 178.54898 & 73.42660 \\
\hline $\mathrm{B}-\mathrm{C}_{2}-\mathrm{C}_{3}-\mathrm{C}_{9}$ & --- & --- & --- & --- & --- & 89.77101 \\
\hline $\mathrm{C}_{1}-\mathrm{C}_{2}-\mathrm{C}_{3}-\mathrm{C}_{9}$ & 1.21045 & -0.00397 & 0.00000 & 1.73259 & 1.55087 & 16.34794 \\
\hline $\mathrm{C}_{2}-\mathrm{C}_{3}-\mathrm{C}_{9}-\mathrm{C}_{8}$ & -0.25985 & 0.00000 & 0.00000 & -0.60049 & -1.58258 & -10.04310 \\
\hline $\mathrm{C}_{8}-\mathrm{C}_{1}-\mathrm{C}_{2}-\mathrm{C}_{3}$ & -1.60868 & 0.00385 & 0.00000 & -2.16235 & -0.87733 & -16.34587 \\
\hline $\mathrm{ZPE}^{\mathrm{C}}$ & 0.1407435 & 0.13641949 & 0.1418039 & 0.1381100 & 0.138373 & 0.142049 \\
\hline Eel & -373.286206 & -373.273922 & -373.297751 & -373.245477 & -373.245865 & -373.27141 \\
\hline$E_{a}=E \mathrm{el}+Z P E^{c}$ & -373.145462 & -373.137502 & -373.155947 & -373.107366 & -373.1074915 & -373.129360 \\
\hline$\Delta E_{a}^{b}($ Hartree $)$ & 0.010485 & 0.018445 & 0.00 & 0.048581 & 0.048455 & 0.026587 \\
\hline$\Delta E_{a}\left(\mathrm{kcal} \mathrm{mol}{ }^{-1}\right)$ & 6.57 & 11.57 & 0.00 & 30.48 & 30.405 & 16.68 \\
\hline$E_{\mathrm{a}}^{\mathrm{c}}\left(\mathrm{kcal} \mathrm{mol}^{-1}\right)$ & & & & 23.91 & 18.83 & 10.11 \\
\hline$\Delta H$ & & & & 5.00 & -11.57 & 0.00 \\
\hline
\end{tabular}

${ }^{a}$ Corrected by multiplying by a scaling factor $(0.9409)$.

${ }^{\mathrm{b}}$ Relative to the most stable structure

Table2. HF/6-311+G** Calculated Single Point Structural Parameters and Energies of the Ground States and Transition States of 1 -indenyl(dihydro)borane

\begin{tabular}{|c|c|c|c|c|c|c|}
\hline Compounds & 1 & 2 & 3 & $\overline{1 \rightarrow 2}$ & $2 \rightarrow 3$ & $1 \rightarrow 1^{\prime}$ \\
\hline$Z P E^{a}$ & 0.1407435 & 0.13641949 & 0.1418039 & 0.1381100 & 0.138373 & 0.142049 \\
\hline Eel & $\begin{array}{c}- \\
370.7891546\end{array}$ & $\begin{array}{c}- \\
370.7666385\end{array}$ & $\begin{array}{c}- \\
370.8010636\end{array}$ & $\begin{array}{c}- \\
370.7269038\end{array}$ & -370.731217 & 370.7508864 \\
\hline$E_{a}=E \mathrm{el}+Z P E$ & -370.648411 & $\begin{array}{c}- \\
370.6302190\end{array}$ & $\begin{array}{c}- \\
370.6592597\end{array}$ & $\begin{array}{c}- \\
370.5887938\end{array}$ & -370.592844 & 370.6088374 \\
\hline$\Delta E_{\mathrm{a}}^{\mathrm{b}}($ Hartree $)$ & 0.0108487 & 0.0290407 & 0.00 & 0.0704659 & 0.0664157 & 0.0504223 \\
\hline$\Delta E_{a}\left(\mathrm{kcal} \mathrm{mol}^{-1}\right)$ & 6.80 & 18.22 & 0.00 & 44.21 & 41.67 & 31.63 \\
\hline$E_{\mathrm{a}}^{\mathrm{c}}\left(\mathrm{kcal} \mathrm{mol}{ }^{-1}\right)$ & & & & 37.41 & 23.45 & 24.83 \\
\hline$\Delta H$ & & & & 11.42 & -18.22 & 0.00 \\
\hline
\end{tabular}


Table 3. MP2/6-311+G** Calculated Single Point Structural Parameters and Energies of the Ground States and Transition States of 1-indenyl(dihydro)borane

\begin{tabular}{|c|c|c|c|c|c|c|}
\hline Compounds & 1 & 2 & 3 & $1 \rightarrow 2$ & $2 \rightarrow 3$ & $1 \rightarrow 1^{\prime}$ \\
\hline ZPE & 0.1407435 & 0.13641949 & 0.1418039 & 0.1381100 & 0.138373 & 0.142049 \\
\hline Eel & $\begin{array}{c}- \\
372.1147183\end{array}$ & $\begin{array}{c}- \\
372.0951642\end{array}$ & 372.1245096 & $\begin{array}{c}- \\
372.0754224\end{array}$ & $\begin{array}{c}- \\
372.0732901\end{array}$ & -372.104577 \\
\hline$E_{a}=E \mathrm{el}+Z P E$ & $\begin{array}{c}- \\
371.9739748\end{array}$ & $\begin{array}{c}- \\
371.9587447\end{array}$ & $\begin{array}{c}- \\
371.9827057\end{array}$ & $\begin{array}{c}- \\
371.9373124\end{array}$ & $\begin{array}{c}- \\
371.9349171\end{array}$ & -371.962528 \\
\hline$\Delta E_{\mathrm{a}}^{\mathrm{b}}($ Hartree $)$ & 0.0087309 & 0.023961 & 0.00 & 0.045393 & 0.047788 & 0.0201777 \\
\hline$\Delta E_{a}\left(\mathrm{kcal} \mathrm{mol}^{-1}\right)$ & 5.47 & 15.03 & 0.00 & 28.48 & 29.98 & 12.66 \\
\hline$E_{\mathrm{a}}^{\mathrm{c}}\left(\mathrm{kcal} \mathrm{mol}{ }^{-1}\right)$ & & & & 17.43 & 14.95 & 7.19 \\
\hline$\Delta H$ & & & & 9.56 & -15.03 & 0.00 \\
\hline
\end{tabular}

Table 4. B3LYP/lanl2dz Calculated Structural Parameters and Energies of the Ground States and TransitionStates of -indenyl(tricarbonyl)cobalt..Bond Lengths are in Angstrom Units $(\AA)$ and Angles in Degrees $(\stackrel{\circ}{)})$

\begin{tabular}{|c|c|c|c|c|c|c|c|}
\hline Compounds & 1 & 2 & 3 & $1 \prime$ & $1 \rightarrow 2$ & $2 \rightarrow 3$ & $1 \rightarrow 1^{\prime}$ \\
\hline \multicolumn{8}{|l|}{ Bond lengths } \\
\hline Co- $\mathrm{C}_{1}$ & 2.0823 & 1.9687 & 1.97477 & ---- & 1.9738 & 1.9729 & 2.2281 \\
\hline $\mathrm{Co}-\mathrm{C}_{2}$ & --- & --- & --- & 2.0581 & --- & ---- & 2.1700 \\
\hline $\mathrm{C}_{1}-\mathrm{C}_{2}$ & 1.4925 & 1.5288 & 1.3680 & 1.4386 & 1.5195 & 1.4349 & 1.4561 \\
\hline $\mathrm{C}_{2}-\mathrm{C}_{3}$ & 1.3735 & 1.5153 & 1.5263 & 1.4386 & 1.4265 & 1.51227 & 1.4465 \\
\hline $\mathrm{C}_{3}-\mathrm{C}_{9}$ & 1.4679 & 1.3759 & 1.5193 & 1.4869 & 1.4195 & 1.4239 & 1.4224 \\
\hline $\mathrm{C}_{1}-\mathrm{C}_{8}$ & 1.47509 & 1.3869 & 1.4871 & 1.4869 & 1.4426 & 1.4321 & 1.4462 \\
\hline $\mathrm{C}_{3}-\mathrm{H}_{2}$ & 1.083 & 1.0845 & 1.1010 & 1.0840 & 1.0826 & 1.0824 & 1.0836 \\
\hline $\mathrm{C}_{1}-\mathrm{H}_{1}$ & 1.086 & --- & --- & 1.0840 & 1.4102 & --- & 1.0839 \\
\hline $\mathrm{C}_{2^{-}}-\mathrm{H}_{1}$ & --- & 1.1023 & --- & 1.0810 & 1.2882 & 1. 2822 & 1.0848 \\
\hline $\mathrm{C}_{3}-\mathrm{H}_{1}$ & --- & --- & 1.1010 & -- & --- & 1.4112 & ---- \\
\hline \multicolumn{8}{|l|}{ Occupancy } \\
\hline Co- $\mathrm{C}_{1}$ & $\delta=1.72311$ & $\delta=1.74311$ & $\delta=1.75148$ & $\delta=1.63217$ & $\delta=1.78323$ & 1.74890 & ---- \\
\hline $\mathrm{Co}-\mathrm{C}_{2}$ & -- & & --- & & - & & --- \\
\hline $\mathrm{C}_{1}-\mathrm{C}_{2}$ & $\delta=1.97509$ & $\delta=1.97008$ & $\delta=1.97911$ & $\delta=1.97372$ & $\delta=1.92836$ & $\delta=1.97547$ & $\delta=1.96837$ \\
\hline \multirow[t]{2}{*}{$\mathrm{C}_{2}-\mathrm{C}_{3}$} & $\delta=1.98003$ & $\delta=1.97182$ & $\delta=1.96906$ & $\delta=1.97453$ & $\delta=1.97599$ & $\delta=1.93681$ & $\delta=1.97695$ \\
\hline & $\Pi==1.86540$ & & & $\pi==1.61057$ & $\begin{array}{c}\pi== \\
1.67259\end{array}$ & & \\
\hline \multirow[t]{2}{*}{$\mathrm{C}_{3}-\mathrm{C}_{9}$} & $\delta=1.97187$ & $\delta=1.97970$ & $\delta=1.97430$ & $\delta=1.97258$ & $\delta=1.97472$ & $\delta=1.97727$ & $\delta=1.97383$ \\
\hline & & $\pi=1.81127$ & & & & $\pi=1.62918$ & $\pi=1.62762$ \\
\hline \multirow[t]{2}{*}{$\mathrm{C}_{1}-\mathrm{C}_{8}$} & $\delta=1.96700$ & $\delta=1.97588$ & $\delta=1.96729$ & $\delta=1.97194$ & $\delta=1.97292$ & $\delta=1.97064$ & $\delta=1.97326$ \\
\hline & & $\pi=1.76281$ & & & $\pi=1.59625$ & $\pi=1.63203$ & $\pi=1.60305$ \\
\hline $\mathrm{C}_{3}-\mathrm{H}_{2}$ & $\delta=1.98064$ & $\delta=1.98053$ & $\delta=1.95430$ & $\delta=1.98174$ & $\delta=1.97890$ & $\delta=1.98197$ & \\
\hline $\mathrm{C}_{1}-\mathrm{H}_{1}$ & $\delta=1.97173$ & --- & --- & $\delta=1.98086$ & --- & ---- & $\delta=1.97727$ \\
\hline $\mathrm{C}_{2}-\mathrm{H}_{1}$ & --- & $\delta=1.94217$ & --- & ---- & $\delta=1.97930$ & $\delta=1.97854$ & $\delta=1.97695$ \\
\hline $\mathrm{C}_{3}-\mathrm{H}_{1}$ & --- & --- & $\delta=1.95401$ & --- & --- & --- & $\delta=1.98191$ \\
\hline
\end{tabular}




\begin{tabular}{|c|c|c|c|c|c|c|c|}
\hline \multicolumn{8}{|l|}{ Bond angles $\left({ }^{\circ}\right)$} \\
\hline Co- $\mathrm{C}_{1}-\mathrm{C}_{2}$ & 117.265 & 122.795 & 128.815 & 63.857 & 127.788 & 125.596 & 68.523 \\
\hline $\mathrm{Co}-\mathrm{C}_{1}-\mathrm{C}_{8}$ & 76.578 & 129.727 & 122.737 & 99.828 & 127.097 & 127.393 & 111.353 \\
\hline $\mathrm{Co}-\mathrm{C}_{2}-\mathrm{C}_{3}$ & --- & --- & --- & --- & --- & & 108.748 \\
\hline $\mathrm{C}_{1}-\mathrm{C}_{2}-\mathrm{C}_{3}$ & 110.393 & 104.824 & 111.424 & 106.305 & 109.023 & 108.524 & 118.467 \\
\hline $\mathrm{C}_{2}-\mathrm{C}_{3}-\mathrm{C}_{9}$ & 108.721 & 108.692 & 102.551 & 107.766 & 108.037 & 106.091 & 108.185 \\
\hline $\mathrm{C}_{3}-\mathrm{C}_{9}-\mathrm{C}_{8}$ & 107.730 & 109.234 & 108.924 & 107.029 & 109.215 & 108.446 & 108.179 \\
\hline $\mathrm{C}_{9}-\mathrm{C}_{8}-\mathrm{C}_{1}$ & 108.176 & 109.769 & 108.652 & 107.031 & 119.332 & 109.886 & 108.363 \\
\hline $\mathrm{C}_{8}-\mathrm{C}_{1}-\mathrm{C}_{2}$ & 104.765 & 107.477 & 108.447 & 107.769 & 104.336 & 107.009 & 106.718 \\
\hline \multicolumn{8}{|l|}{$\begin{array}{c}\text { Torsion } \\
\text { angles }\left({ }^{\circ}\right)\end{array}$} \\
\hline Co- $\mathrm{C}_{1}-\mathrm{C}_{2}-\mathrm{C}_{3}$ & -79.222 & 179.796 & 179.988 & --- & -168.039 & 177.880 & -104.565 \\
\hline Co- $\mathrm{C}_{2}-\mathrm{C}_{3}-\mathrm{C}_{9}$ & --- & --- & --- & 92.334 & --- & ---- & -80.622 \\
\hline $\mathrm{C}_{1}-\mathrm{C}_{2}-\mathrm{C}_{3}-\mathrm{C}_{9}$ & -0.3962 & 0.0314 & 0.00000 & 19.870 & -1.6289 & 2.1033 & -3.0516 \\
\hline $\mathrm{C}_{2}-\mathrm{C}_{3}-\mathrm{C}_{9}-\mathrm{C}_{8}$ & -2.5393 & -0.0042 & 0.0109 & -12.313 & 0.2636 & -1.4509 & 2.5691 \\
\hline $\mathrm{C}_{8}-\mathrm{C}_{1}-\mathrm{C}_{2}-\mathrm{C}_{3}$ & 3.0747 & -0.0482 & -0.0107 & -19.866 & 2.3406 & -1.9063 & 2.3156 \\
\hline $\mathrm{ZPE}^{\mathrm{C}}$ & 0.145825 & 0.144513 & 0.145733 & 0.146057 & 0.144425 & 0.141616 & 0.145364 \\
\hline Eel & -832.1312 & -832.0846 & -832.1186 & -832.1274 & -832.0491 & -832.0484 & -832.1064 \\
\hline$E_{a}=E \mathrm{el}+Z P E$ & -831.985375 & -831.940087 & -831.972867 & -831.981343 & -831.904675 & -831.906784 & -831.961036 \\
\hline$\Delta E_{\mathrm{a}}^{\mathrm{b}}($ Hartree $)$ & 0.00 & 0.045288 & 0.012508 & 0.004032 & 0.0807 & 0.078591 & 0.024339 \\
\hline$\Delta E_{a}\left(\mathrm{kcal} \mathrm{mol}{ }^{-1}\right)$ & 0.00 & 28.41 & 7.84 & 2.53 & 50.63 & 49.31 & 15.27 \\
\hline$E_{a}^{c}(\mathrm{kcal} \mathrm{mol}-1)$ & & & & & 50.63 & 20.9 & 15.27 \\
\hline$\Delta H$ & & & & & 28.36 & -20.92 & 2.56 \\
\hline \multicolumn{8}{|c|}{${ }^{a}$ Corrected by multiplying by a scaling factor $(0.9409)$. } \\
\hline Table 5. B3 & $Y P / 6-311+G^{\star \star}$ & \multicolumn{6}{|c|}{${ }^{\mathrm{b}}$ Relative to the most stable structure } \\
\hline Compounds & 1 & 2 & 3 & $1{ }^{\prime}$ & $1 \rightarrow 2$ & $2 \rightarrow 3$ & $1 \rightarrow 1$ \\
\hline$Z P E^{a}$ & 0.145825 & 0.144513 & 0.145733 & 0.146057 & 0.144425 & 0.141616 & 0.145364 \\
\hline Eel & -2070.1316 & -2070.0852 & -2070.1200 & -2070.1376 & -2070.0648 & -2070.0546 & -2070.1114 \\
\hline$E_{a}=E \mathrm{el}+Z P E$ & -2069.98577 & -2069.94068 & -2069.97426 & -2069.99154 & -2069.91138 & -2069.91298 & -2069.96603 \\
\hline$\Delta E_{\mathrm{a}}^{\mathrm{b}}($ Hartree $)$ & 0.005768 & 0.050856 & 0.017276 & 0.00 & 0.0801593 & 0.078559 & 0.025507 \\
\hline$\Delta E_{a}\left(\mathrm{kcal} \mathrm{mol}^{-1}\right)$ & 3.61 & 31.91 & 10.84 & 0.00 & 50.3 & 49.29 & 16.00 \\
\hline$E_{\mathrm{a}}^{\mathrm{c}}\left(\mathrm{kcal} \mathrm{mol}{ }^{-1}\right)$ & & & & & 46.69 & 17.38 & 12.39 \\
\hline$\Delta H$ & & & & & 28.24 & -21.03 & -3.61 \\
\hline
\end{tabular}


Taable 6. HF/6-311+G** Calculated Single Point Structural Parameters and Energies of the Ground States and Transition States of 1-indenyl(tricarbonyl)cobalt

\begin{tabular}{|c|c|c|c|c|c|c|c|}
\hline Compounds & 1 & 2 & 3 & $1 '$ & $1 \rightarrow 2$ & $2 \rightarrow 3$ & $1 \rightarrow 1^{\prime}$ \\
\hline $\mathrm{ZPE}^{\mathrm{a}}$ & 0.145825 & 0.144513 & 0.145733 & 0.146057 & 0.144425 & 0.141616 & 0.145364 \\
\hline Eel & -2064.37293 & -2064.33268 & -2064.3760 & -2064.37035 & -2064.30028 & -2064.29053 & -2064.36544 \\
\hline$E_{a}=E \mathrm{el}+Z P E$ & -2064.22710 & -2064.18816 & -2064.2303 & -2064.2243 & -2064.15586 & -2064.14891 & -2064.22008 \\
\hline$\Delta E_{\mathrm{a}}^{\mathrm{b}}($ Hartree $)$ & 0.003204 & 0.0421422 & 0.00 & 0.006011 & 0.074449 & 0.0813928 & 0.01023 \\
\hline$\Delta E_{a}\left(\mathrm{kcal} \mathrm{mol}^{-1}\right)$ & 2.01 & 26.44 & 0.00 & 3.77 & 46.71 & 51.07 & 6.41 \\
\hline$E_{\mathrm{a}}^{\mathrm{C}}\left(\mathrm{kcal} \mathrm{mol}{ }^{-1}\right)$ & & & & & 44.70 & 24.63 & 4.40 \\
\hline$\Delta H$ & & & & & 24.38 & -26.39 & 1.76 \\
\hline
\end{tabular}

Table 7. MP2/6-311+G* Calculated Single Point Structural Parameters and Energies of the Ground States and Transition States of 1-indenyl(tricarbonyl)cobalt

\begin{tabular}{|c|c|c|c|c|c|c|c|}
\hline Compounds & 1 & 2 & 3 & 1 & $1 \rightarrow 2$ & $2 \rightarrow 3$ & $1 \rightarrow 1^{\prime}$ \\
\hline $\mathrm{ZPE}^{\mathrm{a}}$ & 0.145825 & 0.144513 & 0.145733 & 0.146057 & 0.144425 & 0.141616 & 0.145364 \\
\hline Eel & -2067.13836 & -2067.07733 & -2067.11572 & -2067.158092 & -2067.05239 & -2067.05414 & -2067.11326 \\
\hline$E_{a}=E \mathrm{el}+Z P E$ & -2066.99253 & -2066.93282 & -2066.96998 & -2067.012035 & -2066.90796 & -2066.91252 & -2066.96790 \\
\hline$\Delta E_{\mathrm{a}}^{\mathrm{b}}($ Hartree $)$ & 0.019498 & 0.0792324 & 0.0420466 & 0.00 & 0.1040694 & 0.0995078 & 0.0441299 \\
\hline$\Delta E_{a}\left(\mathrm{kcal} \mathrm{mol}^{-1}\right)$ & 12.23 & 49.71 & 26.38 & 0.00 & 65.30 & 62.44 & 27.69 \\
\hline$\Delta H$ & & & & & 37.48 & -23.33 & -12.23 \\
\hline
\end{tabular}

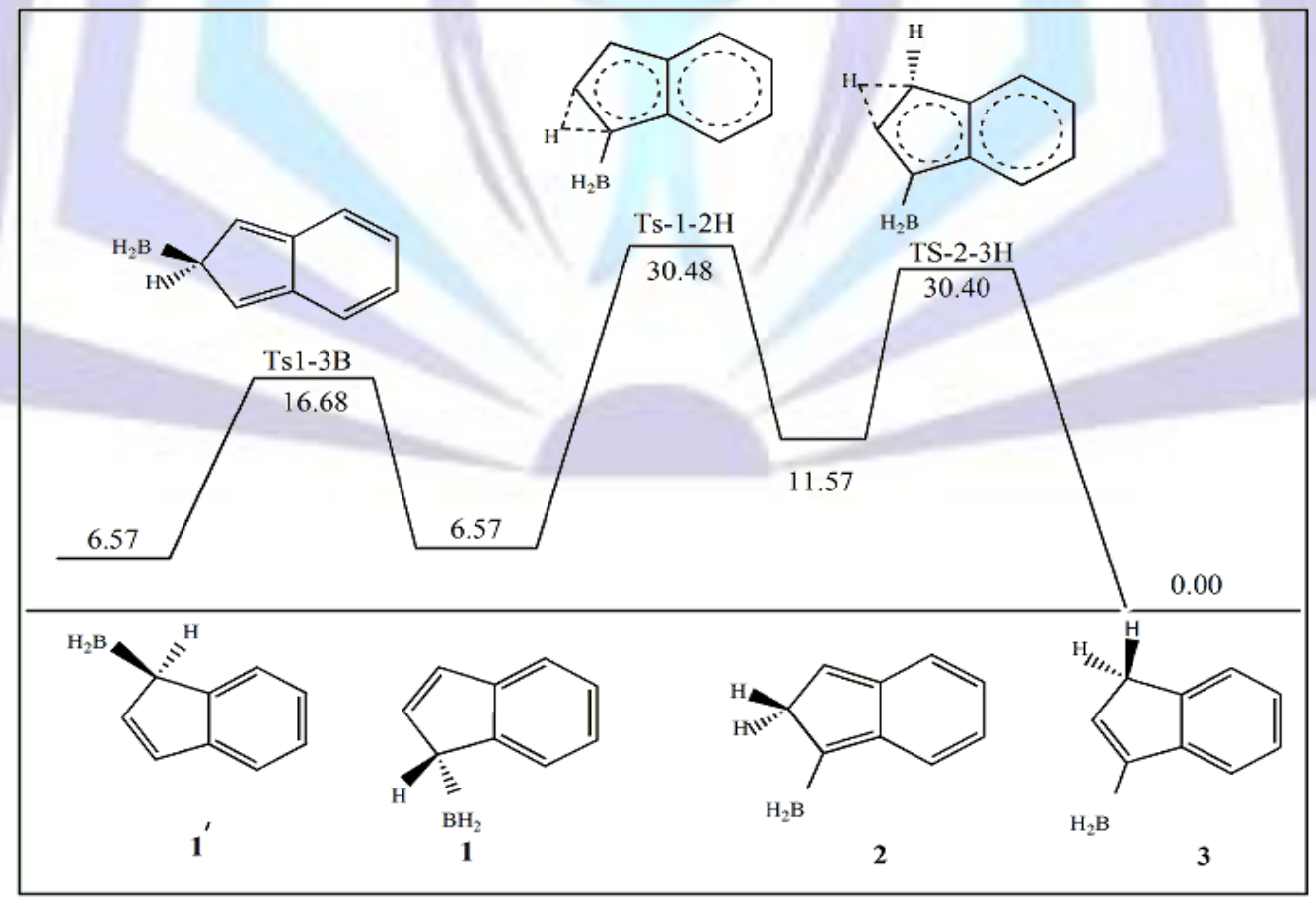

Figure 3: $B 3 L Y P / 6-311+G^{\star \star}$ energy diagram for various sigmatropic shifts in compound 1 


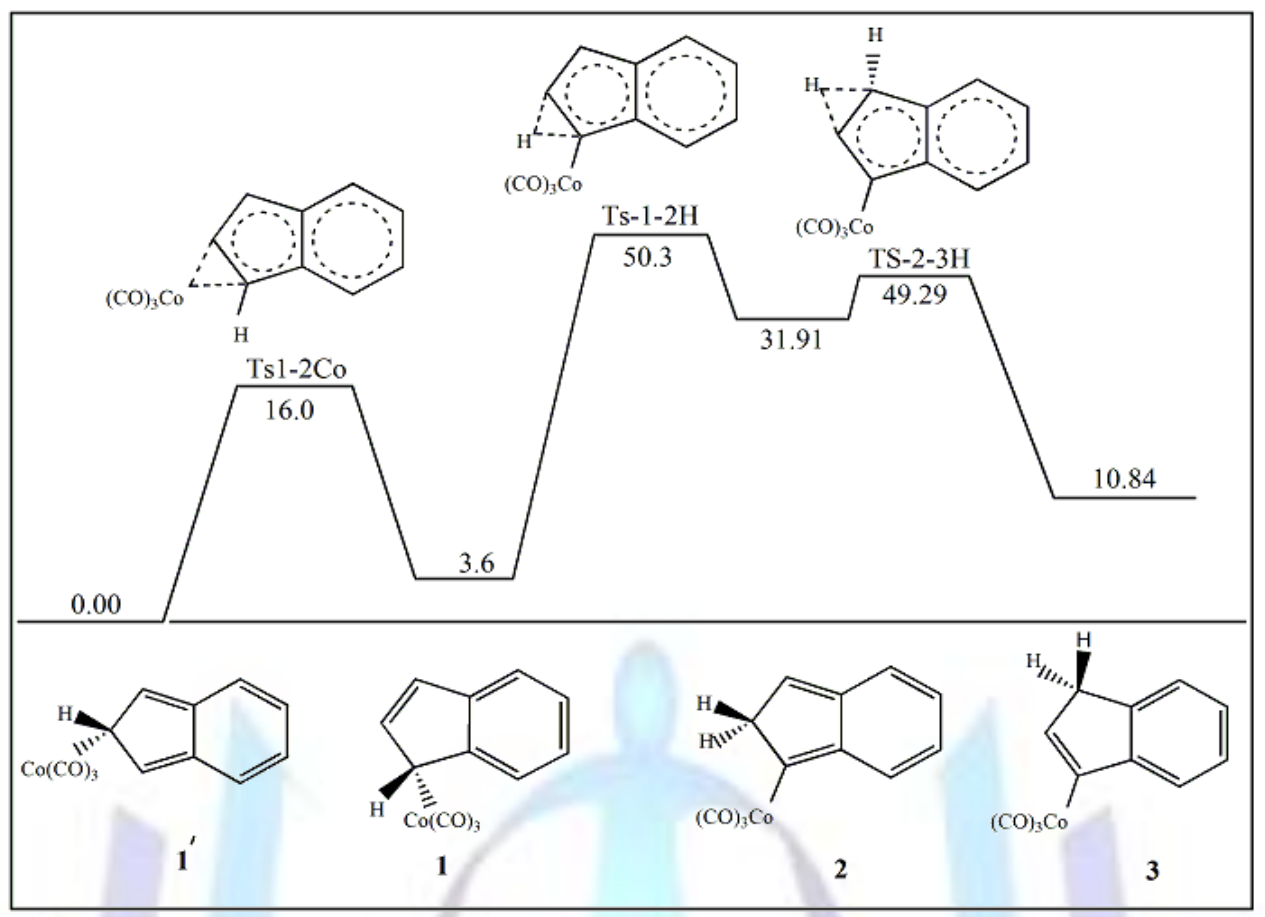

Figure 4: $B 3 L Y P / 6-311+G^{\star *}$ energy diagram for various sigmatropic shifts in compound 2

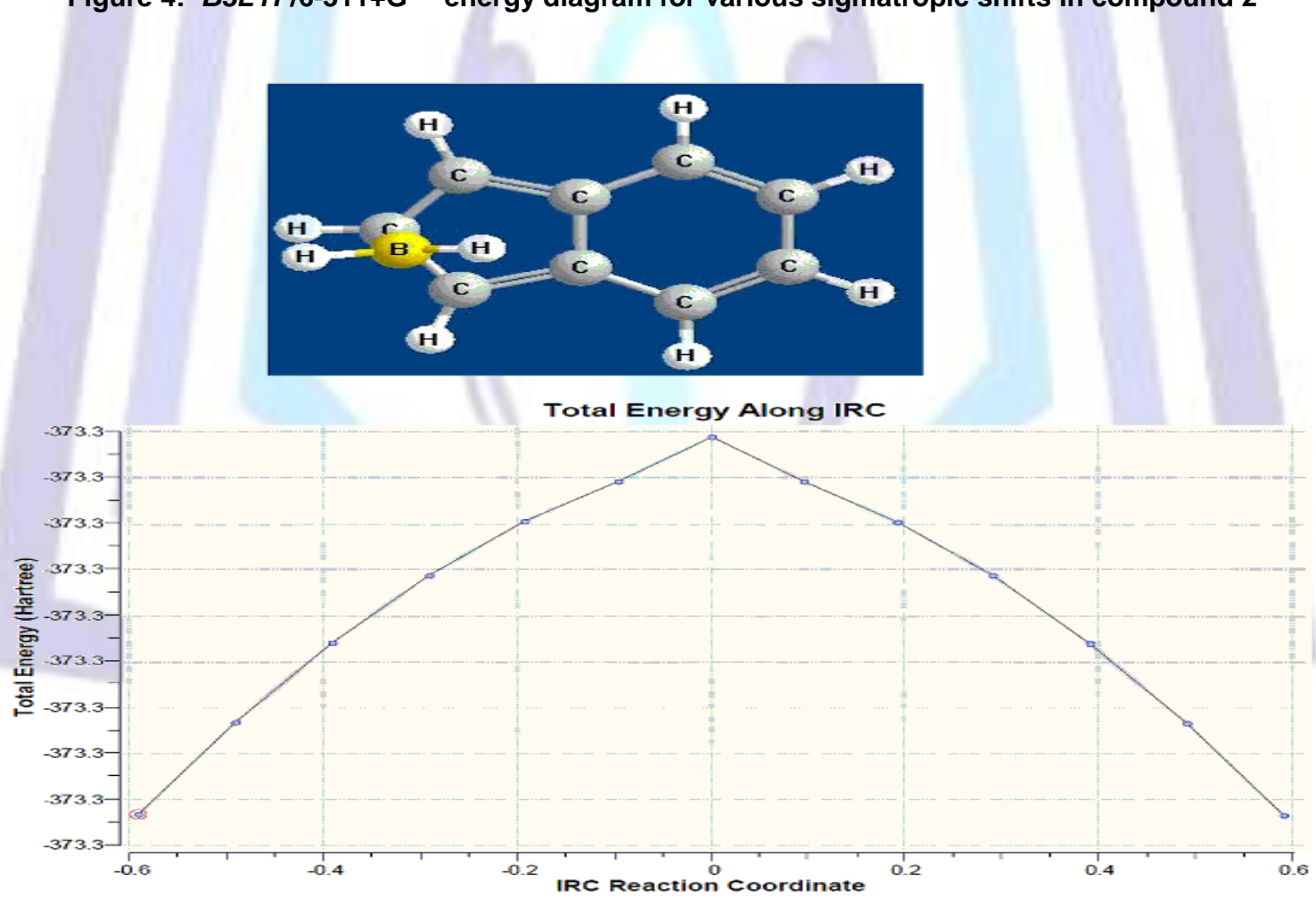

Figure 5: IRC plot of $[1,3]$ shift for borotropic compound 1

\section{REFERENCES}

[1] Wilkinson, G., and Piper, T. S. 1956. Cyclopentadienyl-triethylphosphine-copper(I) and biscyclopentadienylmercury(II). Inorg. Nucl. Chem. 2: 32-37 (b) Piper, T. S., and Wilkinson, G. 1956. Alkyl and aryl derivatives of $\pi$-cyclopentadienyl compounds of chromium, molybdenum, tungsten, and iron. Inorg. Nucl. Chem. 3: 104124.

[2] Fritz, H. P., and Kreiter, C. G. 1965. Spektroskopische untersuchungen an organometallischen verbindungen: XXXIII. $1 \mathrm{H}-\mathrm{NMR}$-spektren von $\sigma$-cyclopentadienylen von metallen der IV. Gruppe. J. Organomet. Chem. 4: 313-319. 
[3] Jutzi, P. 1986. Fluxional .eta.1-cyclopentadienyl compounds of main-group elements. Chem. Rev. 86: 983-996.

[4] Nori-Shargh, D., Aghabozorgh, H., Zare, K., Talei, M. R,. and Jameh-Bozorghi, S. 2003. Ab initio study of structures, metallotropic 1,2-shifts and protropic 1,2-shifts of cyclopentadienyl(trimetyl)- Silane, -Germane and -Stannane. Phosphorus Sulfur and Silicon. 178: 341-351.

[5] Gridnev, I. D., and Meller, A. 1998. Synthesis and dynamic behaviour of. (1-indenyl) diethylborane. Main Group Metal Chem. 21: 121-128.

[6] Wiberg, K. B., and Fenoglio, R. A. 1968. Heats of formation of C4H6 hydrocarbons. J. Am. Chem, Soc. 90: 33953397.

[7] Gielen, M., Willem, R., Wrackmeyer, B. 2004. Fluxional Organometallic And Coordination Compounds, John Wiley \& Sons Ltd, England.

[8] Kisin, A. V., Kovenevsky, V. A., Sergeyev, N. M., and Ustynyuk, Yu. A. 1972. Nuclear magnetic resonance spectroscopy of metal cyclopentadienyls VI. Metallotropic rearrangement in the group IVB cyclopentadienyls, J. Organomet. Chem. 34: 93-104.

[9] Ustynyuk, Yu. A., Zakharov, P. I., Azizov, A. A., Potapov, V. K., and Pribytkova, I. M. 1975. Mass spectra of monohapto-cyclopentadienyl derivatives of group IVB elements. J. Organomet. Chem. 88: 37-64.

[10] Grishin, Yu. K., Sergeyev, N. M., and Ustynyuk, Yu. A. 1972. 13C-NMR spectra of metal $\sigma$-cyclopentadienyls. Organomet. Magnetic Resonance. 4: 377-390.

[11] Hagen, A. P., and Russa, P. J.1973. Fluxional behaviour of 5-(silyl)cyclopentadiene and 5(silyl)methylcyclopentadiene (1,2-isomer mixture), J. Organomet. Chem. 51: 125-133.

[12] Davison, A., and Rakita, P. E.1970. Fluxional behaviour of cyclopentadienyl, methylcyclopentadienyl, and pentamethylcyclopentadienyl compounds of silicon, germanium, and tin. Inorg. Chem. 9: 289-294.

[13] Angus, P. C. and Stobart, S. R. 1973. Stereochemical non-rigidity in germylcyclopentadiene and related derivatives of germane, J. Chem. Soc. Dalton Trans. 2374-2380.

[14] Sergeyev, N. M., Avramenko, G. I., Kisin, A. V. Kovenevsky, V. A., and Ustynyuk, Yu. A. 1971. Nuclear magnetic resonance spectroscopy of metal cyclopentadienyls $V$. Metallotropic rearrangement in silicon cyclopentadienyls: 1,2 shift and spectral regularities in $\sigma$-cyclopentadienyls. J. Organomet. Chem. 32: 55-77.

[15] Cuthbertson, A. F., and Glidewell, C. 1981. The structure of silyl cyclopentadienes. J. Organomet, Chem. 221: $19-31$.

[16] Hoffmann, R. 1982. Building Bridges Between Inorganic and Organic Chemistry, Angewandte Chemie International. Edition. 21: 711-724-.

[17] Becke, A. D.1993. Density-functional thermochemistry. III. The role of exact exchange. J. Chem. Phys. 98: 56485652.

[18] Lee, C., Yang, W., and Parr, R. G.1998. Development of the Colle-Salvetti Correlation-Energy Formula into a Functional of the Electron Density, Phys. Rev. 37: 785-789.

[19] Hehri, W. J., Radom, L., Schleyer, P. V. R., and Pople, J. A. 1986. Ab initio Molecular Orbital Theory.Wiley, New York.

[20] Seminario, J. M., and Politzer, P. 1995. Modern Density Function Theory. A Tool for Chemistry, Elsevier, Amsterdam.

[21] Frisch, M. J., Trucks, G. W., Schlegel, H. B., Scuseria, G. E., Robb, M. A., Cheeseman, J. R., Zakrazewski, V.G., Montgomery, J. A., Startmann, R. E., Burant, J. C., Dapprich, S., Millam, J. M., Daniels, A. D., Kudin, K. N., Strain, M. C., Farkas, O., Tomasi, J., Barone, V., Cossi, M., Cammi, R., Mennucci, B., Adamo, C., Clifford, S., Ochterski, J., Petersson, G. A., Ayala, P. Y., Cui. Q., Morokuma, K., Malik, D. K., Rabuck, A. D., Raghavachar, K., Foresman, J. B., Cioslowski, J., Ortiz, J. V., Stefanov, B. B., Liu, G., Liashenko, A., Piskorz, P., Komaromi, I., Gomperts, R., Martin, R. L., Fox, D. J., Keith, T., Al-Laham, M. A., Peng, C. Y., Nanyakkara, A., Gonzalez, C., Challacombe, M., Gill, P. M. W., Johnson, B., Chen, W., Wong, M.W., Andres, J. L., Head-Gordon, M., Replogle, E. S., and Pople, J. A. 1998. GAUSSIAN 98 (Revision A3), Gaussian Inc, Pittsburgh, PA.

[22] Peng, C., Schlegel, H. B. 1993. Combinig synchronous transit and quasi-newton methods to find transition states. Israel J. of Chem. 33: 449-454.

[23] Peng, C., Ayala, P. Y., Schlegel, H. B., Frisch, M. J.1996. Using redundant internal coordinates to optimize equilibrium geometries and transition states, J Comp Chem. 17: 49-56. 